\title{
Aduloju of Ado: A Nineteenth Century Ekiti Warlord
}

\author{
Emmanuel Oladipo Ojo (Ph.D) \\ Department of History \& International Studies, Ekiti State University, Ado-Ekiti, Ekiti State, NIGERIA
}

\begin{abstract}
For Yorubaland, south-western Nigeria, the nineteenth century was a century of warfare and gunpowder akin, in magnitude and extent, to that of nineteenth century Europe. Across the length and breadth of Yorubaland, armies fought armies until 1886 when Sir Gilbert Carter, British Governor of the Lagos Protectorate, intervened to restore peace. Since men are generally the products of the times in which they live and the circumstances with which they are surrounded; men who live during the period of peace and tranquillity are most likely to learn how to promote and sustain peace while those who live in periods of turbulence and turmoil are most likely to learn and master the art of warfare. As wars raged and ravaged Yoruba nations and communities, prominent men emerged and built armies with which they defended their nations and aggrandised themselves. Men like Latosisa, Ajayi Ogboriefon and Ayorinde held out for Ibadan; Obe, Arimoro, Omole, Odo, Edidi, Fayise and Ogedengbe Agbogungboro for Ijesa; Karara for Ilorin; Ogundipe for Abeokuta; Ologun for Owo; Bakare for Afa; Ali for Iwo, Oderinde for Olupona, Onafowokan and Kuku for Ijebuode, Odu for Ogbagi; Adeyale for Ila; Olugbosun for Oye and Ogunbulu for Aisegba. Like other Yoruba nations and kingdoms, Ado Kingdom had its own prominent warlords. Some of these were Ogbigboniharan of Idolofin Quarters, Ogunmonakin of Okelaja, Eleyinmi Orogirigbona of Okeyinmi, Falowo of Ogbon Ado and Aduloju of Edemo Quarters. The greatest of these men was Aduloju. This paper examines the career and exploits of this great warlord.
\end{abstract}

\section{Introduction: Major Features of the $19^{\text {th }}$ Century Ekiti}

Aduloju was born at Ado Ekiti in 1824 and died in 1902. This made him a man of the nineteenth century Ekiti. For the purposes of clarity and chronology, this paper begins with an outline of the major features of the $19^{\text {th }}$ century Ekiti and proceeds to a brief examination of the events that led to the emergence of Aduloju as a warlord.. Ekiti, a sub-group of the Yoruba of south western Nigeria, occupy the eastern part of Yorubaland and share borders with the Ijesa, Akoko, Igbomina, Owo and Ondo. In the $19^{\text {th }}$ century, like what obtained in other parts of Yorubaland, Ekiti was a land free for all to roam, hunt and cultivate with homesteads and towns of varying sizes dotting the thick vegetation. 'Ekiti' denotes a country of hills and, as Robert Smith has pointed out, this physical feature, more than any other factor, accounts for its division into a number of small kingdoms or city-states. ${ }^{1}$ Ekiti comprised sixteen traditional districts (kingdoms) each with its own king and chiefs making it an agglomeration of separate and independent kingdoms. Generally, Ekiti obas (kings) claim descent from Ife believed to the ancestral home of the Yoruba race. ${ }^{2}$ Being a largely culturally homogenous people, the pattern and structure of government in Ekiti districts was basically similar. Government spanned three levels: lineage, quarter and town. The lineage and quarter were headed by the oldest man in each while the town was headed by the $o b a$. The lineage was the basis of social and political life. The oldest member (olori ebi) presided over the lineage, kept the family shrine, performed rituals, consulted the oracle, settled intra-lineage disputes and allocated land to members to cultivate. A number of lineages made up a quarter. Every Ekiti town or village was a multiple of the above. ${ }^{3}$

Farming was the pivot around which the economy revolved. While the men and boys went to the farm after sunrise, worked throughout the day under the scorching sun and returned in the evenings, the women and girls minded the babies, kept the home clean, fetched water from the neighbouring brooks or springs and helped on the farm during harvest. Life was lived in Ekiti for centuries in this simple form. The people were peaceful, law-abiding, diligent and lovers of rural life. ${ }^{4}$ Like other Yoruba-speaking groups, Ekiti people were superstitious and fetish. Many gods and goddesses were worshipped, the most celebrated ones being Ogun, the god of iron and Ifa, the supposed god of wisdom whose oracle was consulted before any major decision was taken. There were multiple shrines for the lineages, quarters and towns. In addition, sinister spirits and witchcraft were feared. Indeed, every skill, achievement, success or calamity (for example, the outbreak of epidemics) was attributed to supernatural forces: while families that made steady socio-economic progress must have obtained the favour of the deities; those with socio-economic immobility must have incurred their wrath. The same applied to the quarter and the town at large. Another prominent feature of the nineteenth century Ekiti was age-grade. Male members of the same age bracket were grouped together for the purposes of performing certain important tasks in their communities. Some of these were those in ages nine, fifteen, sixteen to twenty- 
five, twenty-six to thirty-five, thirty-six to forty-five, etc. While the first performed no communal services; the second cut grass for community buildings; the third constructed and repaired roads and bridges; the fourth, regarded as full-grown men, repaired the palace, courts and other public buildings and the fifth buried the aged. The last two also served as guards and state ambassadors. ${ }^{5}$

In the event of war, even though there were no standing and professional armies, all able-bodied adult men were expected to join the army and they all went back to their regular occupations as soon as the war was over. A few occupations were however associated with security and war. The hunters formed a para-military society whose members ensured the security of towns and villages, trade routes, markets and farmlands. They also acted as scouts in time of war. Blacksmiths occupied very important position in the society because they 'manufactured' the weapons of war. ${ }^{6}$ Each Ekiti town was led in war by a group of war-chiefs called Elegbe. Professional warfare was hardly known and neither the war-chiefs nor their men had any semblance of military training. Up till the $19^{\text {th }}$ century, weapons of war were generally home-made pieces like cutlasses, swords, spears, bows and arrows. Indeed, up till 1815, Ekiti had not mastered the use of guns on a large scale. ${ }^{7}$ Having attempted an outline of pattern of life in Ekiti in the nineteenth century, let us proceed to a brief analysis of the remote circumstances that led to the emergence of Aduloju as warlord.

\section{The Fall of the Old Oyo Empire and the Rise of Ibadan ${ }^{8}$}

Until the close of the eighteenth century, the Oyo Empire stood out as the most distinguished political achievement of the Yoruba-speaking people. ${ }^{9}$ The strength of the em pire rested heavily on its enormous size and revenue base, a substantial part of which derived from trade with the Central Sudan. ${ }^{10}$ However, by the early nineteenth century, the once vibrant and almost unassailable Oyo Empire had begun to totter. Some of the factors that were responsible for this were monarchical failings, internal crises, constitutional defects and external attacks. ${ }^{11}$ The monarchical failings came with the succession of weak kings to the throne of the Oyo Empire. Samuel Johnson expressed the view that the reigns of Alaafin Odarawu, Kanran, Jayin, Ayibi and Osinyago in the second half of the $17^{\text {th }}$ century were despotic. According to Johnson, while Odarawu was illtempered, Kanran was a tyrant, Jayin was effeminate and dissolute, Ayibi was cruel and Osinyato was weak and ineffective. ${ }^{12}$ Internally, Bashorun Gaha, as head of the Oyomesi (Oyo Council of State), arrogated much power to himself and became the Frankenstein monster of the Kingdom. In office as Prime Minister between 1754 and 1774, he supervised or masterminded the dethronement of four successive Alaafins. The elimination of Gaha was thus the consuming passion of Abiodun, the fifth Alaafin during Gaha's terror reign. Unfortunately however, Alaafin Abiodun devoted excessive time and resources to his mission such that even though he eventually succeeded in eliminating Gaha, it was a pyrrhic victory as excessive state human and material resources had been devoted to achieving it. This impoverished and weakened the state. Alaafin Abiodun, who died in April 1789, was the last Alaafin who really held power in the Old Oyo Empire. This rubbishes Daryll Forde's assertion that the Old Oyo Empire was already in decline by $1700 .{ }^{13}$ On the contrary, Robin Law has demonstrated that the empire actually attained its greatest extent and military strength in the 1780s. ${ }^{14}$ The Oyo Empire began to decline 'in the closing decades of the eighteenth century' and demised 'soon after the opening of the nineteenth'. ${ }^{15}$

Like any other constitution, Oyo Empire's unwritten constitution had certain important defects which produced outcomes that did not augur well for the Empire. Constitutionally, the Oyomesi Council held the powers of life and death over the Alaafin. This was because the former could blackmail the latter and compel him to open a sacred calabash containing charmed parrot eggs. Traditionally, any Alaafin who opened the sacred calabash must abdicate the throne or commit suicide. This conferred awesome and disproportionate leverage in the Bashorun over the Alaafin. The most important consequence of this imbalance was that a strong-will Bashorun, paired with a weak Alaafin, would put the Alaafin in an extremely dangerous position. This possibility played itself out fully in the reign of Bashorun Gaha. This was apparently why the Awujale ${ }^{16}$ of Ijebu, Oba Ademiyewo (1841-1855), observed that while the Ijebu people obeyed and served their king; the Oyo Yoruba made theirs a slave and cowed him down. ${ }^{17}$ Furthermore, constitutionally, the Are Ona Kakanfo ${ }^{18}$ (commander of the army), was strictly out of direct and immediate control of the Alaafin, since, as a war general, he was constitutionally mandated to live outside Oyo metropolis. The implication of this was that an overbearing Are Ona Kankanfo could carve out spheres of influence for himself. Afonja exploited this constitutional loophole and utilised the strategic advantage of a distant satellite base to build up a private military force made up of Muslims and a handful Hausa slaves. With the support of Alimi, a Fulani Muslim cleric, Afonja successfully proclaimed the independence of Ilorin. The pivotal roles played by Gaha and Afonja in the fall of Oyo may have informed the assertion by Atanda that the fall of Oyo was not so much a consequence of any inherent weakness in the constitution of the empire but a consequence of "inordinate ambition of the functionaries of the central government, particularly that of Bashorun Gaha, the head of Oyo Mesi...and Afonja, the Are Ona Kakanfo, Field Marshall of Oyo army". ${ }^{19}$ It must be pointed out however that 
both men did some of the things they did by virtue of the roles Oyo constitution imposed on the offices they occupied.

External aggression against the Oyo Empire also contributed to its fall. Between 1775 and 1780, Lisabi freed Egba from Oyo's suzerainty. Also, the Nupe declared its independence in 1781 while the Bariba of Borgu revolted in 1783. All these reduced the stretch and strength of the empire. Closely related to this were a series of fatal and devastating power shifts and economic dislocations in the coastal parts of the empire particularly in Dahomey between 1781 and 1788. These economic dislocations sapped the empire of its once robust economic base. Finally, for the Oyo Empire, the $19^{\text {th }}$ c brought a wave of Fulani wars. By the early 1820 s, the Fulani Jihadists had captured Ilorin and destroyed Oyo Ile, the ancient capital of the Old Oyo Empire and steadily advanced westwards until they were halted by Ibadan in the Osogbo War of 1840. The Fulani Wars dealt severe blows on the Oyo Empire and hastened its disintegration and fall. The end of the Empire finally came in 1835 when its last Alaafin, Oluewu, was killed by the forces of Abdusalam, the first Fulani emir of Ilorin. Arguing from an economic standpoint, Akinjogbin has downplayed the role of the Fulani jihad in the fall of the Old Oyo Empire.$^{20}$ However, in the light of available evidence, it is difficult to belittle or minimise the role of the IlorinFulani in the fall of Oyo. For example, the Alaafin Majotu was said to have requested Captain Clapperton to help him ward off the Fulani menace. ${ }^{21}$ Indeed, after the Fulani got rid of Afonja, they made themselves masters of Ilorin from where they began what Akintoye refers to as a systematic conquest of the Oyo Empire from the north until Oyo-Ile itself, the ancient capital of the empire, had to be deserted. According to Atanda

\begin{abstract}
With Ilorin as base, the jihadists began a systematic attack on the Old Oyo Empire. The rulers of Oyo and those still loyal to them tried to resist the jihadists. But it was in vain. Thus, the wars fought in the $1820 \mathrm{~s}$ and $1830 \mathrm{~s}$ against the jihadists were lost...in Eleduwe War, the most celebrated of the wars, not only did Oyo lose, but Alaafin Oluewu and the Borgu king, Eleduwe, who allied with him against the jihadists, were also killed. With that battle, the Old Oyo Empire virtually came to an end. ${ }^{22}$
\end{abstract}

\title{
III. Ibadan and the Ajele System
}

Following the collapse of the Old Oyo Empire, the moral and military leadership of the empire disappeared. The Fulani thereafter made Ilorin a base from where attacks were launched against the OyoYoruba country. One major consequence of this was that hundreds of thousands of refugees, fleeing from the Ilorin invaders, streamed into western and southern Yorubaland. Some of these settled in Ekiti, some in Ijesaland, while some moved south-westwards and established such towns as Ijaye and Ibadan. ${ }^{23}$ Ibadan proved the most successful of all these refugees' settlements. It rapidly grew into a militarised principality. As a result of the atmosphere of insecurity that pervaded the length and breadth of Yorubaland which bore close similarities to that of state of unrest in Europe which led to the emergence of serfdom and manorialism, citizens willingly offered themselves as subordinates to war chiefs. Each war chief had his own professional army made up of his sons, relatives, captives in war and freeborn youths..$^{24}$ Thus, the Ibadan army which soon became the overriding power and terror in the whole of Yorubaland was an amalgam of the private armies of these chiefs.

Ibadan became the successor state of Old Oyo and bulwark of defence of the central and eastern Yoruba country, most especially against Ilorin who kept advancing southwards, through Offa, Ikirun and Osogbo. The expansionist tendencies of the Ilorin were checkmated in 1840 following the Osogbo War of that year. ${ }^{25}$ This was followed by a systematic and coordinated expulsion of the Ilorin-Fulani from the areas they had earlier conquered. Having been defeated by the Ibadan in the south, the Ilorin invaded Ekiti, Ijesa and Akoko countries. Desirous of total and wholesale victory over Ilorin, Ibadan forces pursued them to these places and fought a series of battles in the 1840s.By 1854, Ilorin had been completely vanquished and between that year and 1870, large areas of Ijesa, Igbomina, Ekiti and Akoko were conquered and annexed by Ibadan and thus arose Ibadan imperial domination of eastern Yorubaland. Ibadan also included in its empire areas not originally under Oyo. By 1865, Ibadan had become the undisputed conqueror of virtually the entire Ekiti, Ijesa and Akoko axis although pockets of communities in these nations still remained independent. On 4 June 1870, the Ijesa who had proved difficult to control while Ibadan was occupied with the Ijaye War, fell to Ibadan army and in 1874, Ado was conquered and 'annexed' by Ibadan. The fall of Ilesa and Ado kingdom marked the high point of Ibadan power. Thus, Ibadan 'clamped an imperial yoke on the Ijesas and Ekitis ${ }^{26}$ and established a very large composite empire. From the above, it appears that the empire created by Ibadan probably covered more of Yorubaland than the Oyo Empire. The empire comprised Ibadan and its countryside, Ibarapa, Osun, Ife, Ijesa, Ekiti, Igbomina and Akoko. However, Ibadan failed to subdue the Egba and Ijebu who controlled the best and shortest routes from the Yoruba hinterland to the coast.

The subordinate towns controlled by Ibadan came to be administered through officials called ajele, a system similar to that of the former Oyo Empire. The ajele 27 ensured that a vassal town remained loyal to Ibadan. He also ensured that tributes were collected and transmitted regularly to Ibadan, saw to the maintenance of law and order and performed other tasks that may be imposed on him by the Ibadan authorities from time to 
time. ${ }^{28}$ Each of the vassal towns was the responsibility of a babakekere in Ibadan, who administered through an ajele in the town itself. The subordinate towns were distributed among Ibadan chiefs who derived much of their wealth from them. Although, the quality of administration varied, the ajele and their officials in eastern Yorubaland gained a bad reputation for oppression and arrogance. Indeed, among the Ekiti and Ijesa, the ajeles and other Ibadan officials were spoken of as "degenerate, greedy and rapacious people, given to licentiousness and debauchery; forcefully taking or stealing whatever caught their fancy...compelling wives in the presence of their husbands and daughters before their fathers to yield to their insatiable desires" ${ }^{29}$ On a regular basis, the ajele boys visited the market place and seize whatever they needed and in worst instances, they extended their seizures to the un-reaped crops on the farms and the cocked food in the houses. At times, they stationed themselves on the highways and compelled all women returning from the farms to carry their loads to the ajele's compound. ${ }^{30}$ Indeed, the ajele system became the symbol of Ibadan cruelty and the object of hate in many of the various communities under Ibadan hegemony. Moreover, Ibadan armies frequently plundered and ravaged the towns and countryside carrying hundreds of people away to Ibadan as slaves in the process. As should be expected in an age when the possession of a strong army was the most important determinant of state policy and direction, the able-bodied men among the captives were enlisted in the private armies of Ibadan war chiefs.

The military adventures and skills of Ibadan war chiefs had profound impact on some ambitious Ekiti youths. This was because many of the able-bodied youths, who, either as captives or adventurers in Ibadan served as attendants or war-boys in the private armies of Ibadan war chiefs, mastered the military organisation of Ibadan. When such youths regained freedom or escaped from Ibadan military schools, they launched their own military adventures and tried to replicate the Ibadan military system by building personal armies composed of their sons, male relatives, slaves and free-born youths they could capture or captivate. By about 1873, there were many such private armies in Ekiti and neighbouring nations. ${ }^{31}$ One of such armies, which later became famous for its bravery and gallantry, was built and led by Aduloju.

\section{Aduloju: His Exploits and Career}

Aduloju was born in Ado 1824. His mother was Adeyeye while his father was Chief Ategbeomoro the Edemo, one of the highl chiefs in the Ado kingdom. Aduloju's real name was Fasawo Okunkolade but was nicknamed Aduloju apparently because of his excessively black face. ${ }^{32} \mathrm{~A}$ far more important physical abnormality Aduloju had at birth was a few premature teeth. ${ }^{33}$ These glaring abnormalities made Aduloju a mystery child. Indeed, the mystery and superstitious fear that surrounded his birth was heightened with the death of his mother soon after she gave birth to him. In most African traditional and superstitious societies, these 'mysteries' were enough to earn a person, particularly a new-born, a death verdict. That was exactly what Aduloju's family members decided: he was to be thrown away in the night and allowed to die. ${ }^{34}$ But, a princess of $E w i^{35}$ Aroloye called at the Edemo's compound and saved the child and thereafter handed him over to Fayunsin, a senior female member of the family who later adopted Aduloju. ${ }^{37}$ A variant of this tradition says he was actually thrown into a pit but was rescued by Fayunsin. The widespread superstitions about and unpleasant reactions to him made Aduloju's childhood a melancholic one. Rejected, despised, hated and given all sorts of names by family members, he grew up mal-adjusted and hardened. He also detested farming. In an age wherein farming was the pivot around which the economy of the family and that of the entire society revolved, any member of the family who did anything that inhibited the production of sufficient food for the household was a saboteur. Thus, Aduloju's hatred for farming and truancy from the farm swelled the camp of his family members who hated him..$^{38}$ This alienation drove him to the street where he kept the company of mal-adjusted and shiftless characters like himself. Probably to proof his critics wrong, Aduloju learned and practised all sorts of trades amongst which were Ifa divining, preparation and sale of charms, amulets, etc and leather work from which he earned a precarious living. Like his contemporaries, he received his military training at Ibadan and stayed there long enough to have a wife and a son. The circumstances of his leaving Ibadan are not known. Curiously enough, he did not put his training and experience to any immediate use. Oral accounts describe him as a very poor man who earned a precarious living from all sorts of odd jobs. Oral traditions say it was after he met a diviner who predicted a successful military career for him that he ventured into same.

Aduloju gradually attracted some youths to himself and created a small band which he taught the use of arms and gave some semblance of military training. Being not in short supply of youths like himself, Aduloju's 'army' soon expanded and became restive and relatively famous. ${ }^{39}$ The Ijesa-Efon War of 1860 to 1862 provided the opportunity for Aduloju's first major military adventure. It would be recalled that in 1860, the Ijesa decided to settle some old scores with their immediate Ekiti neighbours, notably Efon, Okemesi and Ogotun..$^{40}$ The Ijesa army attacked Efon. The latter, realising the futility of fighting the former alone, appealed to other Ekiti kingdoms for support and Ogotun, Imesi-Igbodo and Ado sent contingents to aid Efon. Aduloju led his army and fought gallantly on the side of Efon. However, the numerically superior Ijesa routed the allies and sacked Efon. ${ }^{41}$ The overwhelming defeat notwithstanding, many people took note of Aduloju's personal bravery. Indeed, it was probably this war that brought Aduloju and Ogedengbe ${ }^{42}$ together for the first time. The 
latter, an Ijesa warlord of the nineteenth century, was said to have been impressed by Aduloju's bravery and looked forward to the possibility of future military alliance with him. Of course, this later happened. One positive outcome of the Ijesa-Efon War was therefore the laying of the foundation of a life-long military partnership between the two men. Till date, the Aduloju-Ogedengbe military alliance is celebrated for its outstanding achievements. ${ }^{43}$

After the Efon encounter, Aduloju and his men went on harassing and molesting strangers and travellers in and around Ado Kingdom. In quest of military adventures and gains, Aduloju and his army gradually extended their rampage and plundering activities to western Akoko country. In the process, Aduloju encroached into the domain of Ayorinde, the Aje of Ibadan. The two men and their armies engaged in a few skirmishes and in a major military encounter in 1872, Aduloju routed Ayorinde's army at Irun and captured their booties, slaves, charms an ammunition. ${ }^{44}$ The above victory probably spurred Aduloju and his men to carry their raids farther afield. They thus began to attack, raid and plunder towns and villages indiscriminately. One such adventure was the unprovoked attack on Osi, a town under the protection of Ewi Atewogboye of Ado Kingdom. the Ewi ordered Aduloju to halt his assault on Osi but the latter defied the Ewi and sacked Osi. This was a defiance of constituted authority for which the Ewi never forgave Aduloju. Meanwhile, the growing popularity of Aduloju and the restiveness and size of his army became a source of concern for Ado authorities. Consequently, the Ewi sought to destroy him and his fledging army.

Having routed Osi in defiance of the Ewi's order, Aduloju and his army headed homewards. Ado authorities therefore ordered an ambush and reprisal attack against him but the ambush plot became known to Aduloju who then altered his itinerary. However, this alteration did not absolve him and his army as they were engaged in a battle on entering the capital (Ado) via the Ojudo area of the town. Aduloju and his 143-man army fought fatally as they were overwhelmingly outnumbered by their rivals. He did not only lose the day; he only barely escaped capture and death. With his fledging army almost completely decimated, Aduloju escaped to Igbemo where six of his men earlier captured by the Ado army joined him. ${ }^{45}$ Determined and resolute, Aduloju built another army at Igbemo and shortly afterwards, his men were ready for military campaigns. As a survival strategy, Aduloju resumed his plundering and raiding adventures particularly in and around Ire and Itaji. Thereafter, he settled at Obo from where he was said to have raided as far as Yagba Districts. ${ }^{46}$ The first major military campaign of Aduloju's new army was the Igbo Alahun campaign of 1873. A brief background to the war may be apposite.

On 5 September 1870, the throne of the Owa of Ilesa became vacant. Two princes - Odigbadigba and Peloye - contested for the throne. Ogedengbe backed the former who, with the support of a section of Ibadan chiefs, was crowned the Owa. However, on 22 May 1871 at Ibadan, Odigbadigba was dethroned and replaced by Peloye, his rival. ${ }^{47}$ Ogedengbe kicked, dethroned the Ibadan puppet and occupied the town. This angered Aare Latosisa, the Are-Ona-Kakanfo and Commander-in-Chief of Ibadan armies who despatched Ajayi Ogboriefon, the Balogun of Ibadan, to crush Ogebengbe's revolt and restore peace to Ilesa. The Ibadan army left Ibadan on 30 December 1872. Apparently sensing defeat, Ogedengbe fled to Idi-Iroko, a village between IpetuIjesa and Erin before the arrival of Ogboriefon and his men in Ilesa. When Ibadan army further pursued him, he fled towards Akure. ${ }^{48}$ It was probably obvious to the Deji of Akure that in his quest to apprehend and punish Ogedengbe for revolting against the authority of Ibadan, Ogboriefon would not spare Akure. The Deji thus felt threatened and, being a no-match for Ibadan, he appealed to his Ekiti neighbours for help and a coalition of Ilesa, Akure, Ita-Ogbolu, Emure and Ado was formed. Having known and applauded each other during the Efon War to which reference has been made, Aduloju led his men to support Ogedengbe. While the allied forces encamped at Ita-Ogbolu, the Ibadan army had its base at Ogotun and the Alahun Forest laid between them. The war took its name from this forest.

The allies recorded a resounding victory over Ogboriefon's army. The Igbo Alahun War brought Aduloju and his new army to limelight. Indeed, Aduloju's bravery and military talents caught the attention of Balogun Ogboriefon and other Ibadan war lords and, in a desperate attempt to enlist Aduloju's support, Latosisa, was said to have initiated the former into the Ogboni Cult so that he might not fight against Ibadan in the event of the outbreak of war involving Ibadan. Latosisa also gave Aduloju an Oranyan sword and a gong. As a mark of appreciation, the former gave the latter twenty slaves ${ }^{49}{ }^{4}$ Thus initiated into the Ogboni Cult, Latosisa out-manoeuvred Aduloju since the latter could no longer engage in open conflict against Ibadan. Ironically, in January 1874, while Aduloju watched helplessly, his birth place was attacked and sacked by Ibadan. Apparently, the Ibadan attacked Ado for the primary objective of subjugating it once and for all so that it would cease allying with Ibadan enemies. ${ }^{50}$ The Ibadan army, which left the metropolis on 8 December 1873, was led by the Are-Ona-Kakanfo himself. The attack was sudden and overwhelming and the fall of Ado dramatic and spontaneous. Ado army met that of Ibadan outside the walls, stood a few hours of combat and rapidly disintegrated into a fleeing mob. ${ }^{51}$ Thus, no serious fighting took place as most of the inhabitants had fled to places of safety (particularly Ise) before the arrival of the Ibadan. The fall of Ado was so embarrassing that leading men of the kingdom converged on Agbado, an Ado sub-town, to appraise the circumstances surrounding 
the inglorious fall of the kingdom. Even though he did not participate in the war, Aduloju took part in the postwar deliberations at Agbado, an Ado suburb. At the end of the deliberations, Ala, the Ado war chief, was removed from the position of Balogun on the grounds of incompetence and negligence and Aduloju was unanimously appointed the Balogun of Ado kingdom, a title he bore till his death..$^{52}$

The first military campaign by Aduloju as the Balogun of Ado Kingdom was against Ise. It would be recalled that the latter did not join the Igbo Alahun Alliance against Ibadan. Members of the alliance therefore detested Ise and threatened her with annihilation. However, Ise had a number of factors in her favour. One, she was a very powerful town with a large population. Two, the town was walled round and breaking into her may be hazardous. Three, being a loyal outpost of Ibadan, she could count on the support of the metropolis in the event of outbreak of war. Reading between the lines, it was obvious to Ise that the outbreak of hostilities with the Igbo Alahun Alliance members was a matter of time and was therefore almost permanently mobilised for war. ${ }^{53}$ At this juncture, two events occurred in quick succession which precipitated hostilities and led to war. First, following the sack of Ado by Ibadan in January 1874, many Ado citizens who had fled to Ise for safety were seized by their 'hosts' and were either sold, killed, handed over to Ibadan authorities or sacrificed to their gods..$^{54}$ Ado authorities took serious exemption to the treatment meted out to their members by Ise people and subsequently despatched Falowo, an emerging warlord, to Ise to investigate the circumstances surrounding the ill-treatment of Ado refugees in Ise. The encounter turned sour and ended in a quarrel with Falowo threatening to pay Ise back in her own coins. The second incident that precipitated the Ise War was the Omodidun-Aseuke affair. In 1874, an Akure man, Omodidun, eloped with Aseuke, a native of Ise and wife to the Deji of Akure. The duo went into hiding in Ise. As should be expected, the Deji issued an ultimatum to the Arinjale of Ise asking him to eject Omodidun and Aseuke from his domain but the Arinjale declined. ${ }^{55}$ The Ise War, which lasted over two years, followed. The Igbo Alahun Alliance fought against Ise in all fronts. Aduloju, the oldest of all the war lords, deployed the largest force and was appointed the grand commander of the allied forces. ${ }^{56}$

Ise, as pointed out earlier, was a large and well fortified town. With a large army and extensive cultivatable land within her walls, Ise put up a stiff and heroic resistance which effectively withstood the allied forces. Indeed, Falowo's 'swordsmanship' and Aduloju's charms and Ifa oracle could not overrun Ise. Since Ise was a loyal outpost of Ibadan, the latter despatched her army to aid Ise but the allied forces retreated before the arrival of the Ibadan army and resumed hostilities after its departure to Ibadan. ${ }^{57}$ Eventually however, the resistance mounted by Ise waned and subsequently crumbled. The allied forces broke into the town, sacked, shared its inhabitants as slaves and burnt it. Aduloju gained considerably from the Ise War. Apart from the fact that his share of slaves and booty immeasurably increased his social standing, his army hitherto made up of indigenes of Ado, became an amalgam of men from disparate places and backgrounds. Aduloju's army was said to have expanded so much that he sold some of his slaves in exchange for arms and ammunition so that he could now carry out large scale military campaigns on his own ${ }^{58}$ Moreover, he settled a large number of his slaves and followers on an extensive farmland where food crops were planted and processed to sustain his unprecedently large army. Aduloju's army expanded and he grew in might. Indeed, hundreds of Ado young men, captivated by Aduloju's bravery and military prowess, poured into his army. Now a man many people craved to follow, he decided to build a permanent camp at Imesi Lashigidi an Ado suburb (now Imesi Ekiti) near the Akoko country. ${ }^{59}$ The camp served as Aduloju's base for about twenty years thereafter. The Lashigidi camp grew rapidly as new settlers poured in from every direction. Many of the new settlers were craftsmen and they came along with their wives, relatives and dependants. The camp soon grew and expanded and Balogun Aduloju became its number one citizen with all the trappings of a king.

Apart from the Idoani War which ended in 1879 , the Ise War was probably the last major military engagement of Aduloju and his army. It would be recalled that despite several appeals and emissaries from Ado authorities, Aduloju refused to fight Ikere, a rival neighbouring village. ${ }^{60}$ Aduloju did not also participate in the Ekitiparapo War ${ }^{61}$ despite the fact that Ogebengbe offered him (Aduloju) the leadership of the alliance and threatened Ado with destruction should Aduloju fail to join forces with the Ekitiparapo alliance against Ibadan. ${ }^{62}$ Many reasons have been advanced for Aduloju's refusal to join the Ekitiparapo. While one school of thought is of the view that Aduloju's vacillation and final refusal to join was not unconnected with the Ogboni oath of friendship with Ibadan to which reference has been made, ${ }^{63}$ another is of the view that Aduloju, through the Ifa oracle, already knew that neither of the combatants would be able to defeat the other and that the war would be protracted and yet inconclusive. ${ }^{64}$ A tradition relates that when Fabunmi envoys visited Ado to rally support for the Ekitiparapo, the Ewi Atewogboye and his chiefs signified the intention of Ado to participate in the confederate war. Emissaries were thereafter sent to Aduloju and Falowo at their Imesi-Lasigidi headquarters, asking them to prepare to lead Ado contingents to Imesi Igboodo, the headquarters of Ekitiparapo. According to this tradition, Aduloju was advanced in age and his sight had started to fail. Consequently, he appointed his lieutenant, Falowo, to take his place. The sword of Oranyan was thereafter brought out and propitiated and the news of Falowo's preparation for war put Ado in a festive mood. Guns and powder were bought for the campaign but while testing one of the new guns; it accidentally discharged accidentally and broke one of 
Falowo's hands. Ashamed of being thus deformed, he committed suicide. ${ }^{65}$ Whatever reasons were responsible for Aduloju vacillation and refusal to join the Ekitiparapo adversely affected the image of Ado among other Ekiti kingdoms. Since Aduloju's career would have climaxed with the Ekitiparapo, he lost the attendant prestige and honour he would have earned from participating in the war.

While the Ekitiparapo were fighting Ibadan, Aduloju concentrated on a series of less rigorous military campaigns against the Akoko and their neighbours. After 1879, Aduloju sacked several towns in Afemai and Yagba countries. Aduloju's subjugation of the Akoko country climaxed with the sack of Afa, a large and powerful town situated on a hill and surrounded by a very dense thorn forest. ${ }^{66}$ Having sacked and plundered Afa, Aduloju, in alliance with the Nupe, invaded several Yagba towns in the okun-un Yoruba country. However, Aduloju-Nupe alliance soon broke down and the former, fighting on the side of Oka (in the Akoko country), humiliated the Nupe. The Oka War was Aduloju's last campaign. ${ }^{67}$ The Ekitiparapo War ended all warfare in Yorubaland. After 1886, the British outlawed raiding-for-slave activities and gradually began to establish their control over Yorubaland. Since plundering and raiding activities were very profitable to the warlords and their boys, it was not easy for the various warlords to keep their boys in check; complaints of plundering and raiding activities always reached Captain R.L. Bower, the first (British) Resident at Ibadan. Consequently, Bower drew up "a list...of troublesome spirits [warlords] of the country" 68 and resorted to arresting them. This led to the arrest of those leading war chiefs who or whose war boys continued to engage in plunder and raids. Ogedengbe was arrested in June 1894 and Fabunmi Okemesi in the following year. Although Aduloju, now old, no longer engaged in plundering and raiding activities, his boys still did. Consequently, in 1898, Aduloju was arrested at his Imesi-Lasigidi camp, handcuffed and taken to the Odo-Otin garrison (near Ijabe) where he met Captain Bower. The latter accused Aduloju of engaging in plunder a charge Aduloju denied although he admitted that his war boys raided against his orders. Bower thereafter sternly warned and released him same day. ${ }^{69}$

Aduloju did not return to his Lasigidi camp. This was apparently because the camp had been deserted following his arrest. ${ }^{70}$ Since he admitted that his war-boys raided against his orders, Aduloju might have wanted to separate from the few of them that may have remained at the Lasigidi camp so as to avoid the wrath of Captain Bower who was determined to humiliate anyone who engaged in brigandage. ${ }^{71}$ Aduloju therefore returned to Ado his birth-place, built a large compound and settled his large family there. Shortly after his return, Ado authorities requested him to occupy the Edemo stool that had been vacant for fifteen years since his father died but he declined. ${ }^{72}$ About three and a half years later (July 1902), he died shortly after a meeting with his children where he admonished them to uphold his legacy, seek to succeed through hard-work and shun acts that could tarnish the name of the family.

\section{Conclusion}

In this paper, an attempt was made at reconstructing aspects of Aduloju's tortuous but eventful life. Denied of the traditional familial affection and care and despised at every turn, Aduloju grew up maladjusted; but he rose above all odds and carved a niche for himself. Today, Aduloju remains the most celebrated warlord in the annals of Ado Kingdom and one of the most celebrated in Yorubaland. Whatever might have been his misdemeanours or perceived lack of patriotism particularly his sack of Osi, his failure to declare war on Ikere and refusal to join the Ekitiparapo War, Aduloju was a gallant and brave soldier; a dogged and stringent fighter; a determined and dedicated leader and an audacious and painstaking strategist. His prowess was awesome and admired by both friends and foes. Determined to succeed, Aduloju turned his initial serial failures into sustained striking success.

\section{Notes and References}

[1]. $\quad$ Robert Smith, Kingdoms of the Yoruba (London: Methuen \& Co. Ltd., 1976), p. 62.

[2]. For a detailed examination of the ((exaggerated?) importance of Ile-Ife in Yoruba history, see M.A, Fabunmi, Ife: Genesis of the Yoruba Race (Lagos: John West Publications Ltd., 1985). For another detailed analysis of the primacy of Ile-Ife in Yoruba history, see Toyin Falola \& Dare Oguntomisin The Military in Nineteenth Century Yoruba Politics (Ile-Ife: University of Ife University Press), pp. 17-35.

[3]. Daryll Forde, 'The Yoruba-Speaking Peoples of South-Western Nigeria' (London: International African Institute, 1962), p. 58.

[4]. National Achieves Ibadan: W.A.C. Weir, Intelligence Report on Ado District of Ekiti Division, Ondo Province, October, 1934, p.58.

[5]. G.O.O. Olomola, Aduloju of Ado-Ekiti. A Case Study of An Ekiti Warrior Chief of the Nineteenth Century, An Original Essay for the B.A. History, University of Ife, Ile-Ife, June. 1967, p. 3.

[6]. Toyin Falola and G.O. Oguntomisin, Yoruba Warlords of the $19^{\text {th }}$ Century (Trenton: Africa World Press Inc, 2001), p. 14.

[7]. Jacob Egharevba, A Short History of Benin (Ibadan: Ibadan University Press, 1960), p. 47.

[8]. Ibadan, the capital of the defunct Western Region, was founded in c. 1829. Right from inception, Ibadan acquired a cosmopolitan outlook. Its population comprised Oyo, Egba, Ijebu, Ife and other elements from other parts of Yorubaland. One major factor in favour of Ibadan was its open nature. Unlike other Yoruba towns, Ibadan offered a lot of scope for individual achievement and merit. Thus, by 1831, the population of Ibadan was about 100,000. See Bolanle Awe "Ibadan, Its Early Beginnings" in P.C. Lloyd et. al. (eds.), The City of Ibadan (Cambridge: Cambridge University Press, 1967), p. 15. For another detailed analysis of the founding, growth and government of Ibadan, see Toyin Falola \& Dare Oguntomisin op. cit., pp. 44-60.

[9]. J.A. Atanda has pointed out that many authors (particularly Samuel Johnson) created the notion that, at her peak, the Old Oyo Empire embraced the whole of Yorubaland. According to Atanda, while the fact that the Old Oyo Empire was vast and extensive is 
incontrovertible; it never covered the entire Yorubaland. See his The New Oyo Empire (London: Longman, 1979), pp. 1-3. It must be conceded however, as Akintoye has observed, that the influence of Oyo considerably curtailed the frequency and severity of conflicts among the other Yoruba nations that were not directly under the control of the Oyo Empire. S.A. Akintoye, Revolution and Power Politics in Yorubaland, 1840-1893 (London: Longman, 1971), p. xvi.

[10]. Olatunji Ojo "Ethnic Identity and Nineteenth Century Yoruba Warfare" @ http://www.yorku.ca/nhp/seminars/2003. This site was assessed on 3 July 2013.

[11]. For a detailed analysis of the factors that were responsible for the fall of the Old Oyo Empire, see Robin Law, The Oyo Empire, $c$. 1600 - c.1836 (Oxford: Clarendon Press, 1977), particularly chapter four "The Fall of Oyo", pp. 278-299.

[12]. Johnson, The History of the Yoruba (Lagos: CSS Bookshop, 1921), p.

[13]. See Daryll Forde, 'The Yoruba-Speaking Peoples of South-Western Nigeria' op. cit., p.4.

[14]. Robin Law, op. cit., p. 245.

[15]. S.A. Akintoye, Revolution and Power Politics in Yorubaland, 1840-1893, op. cit.,p. xvi.

[16]. Title of the oba (king) of Ijebu, Ogun State, western Nigeria.

[17]. See E.A. Ayandele, The Ijebu of Yorubaland, 1850-1950: Politics, Economy and Society (Ibadan: Heinemann, 1992$)$, p. 4.

[18]. Fabunmi and Robin Law opine that the title of Are-Ona-Kakanfo was first conferred by Alaafin Ajagbo in about 1600. M.A, Fabunmi, Ife: Genesis of the Yoruba Race (Lagos: John West Publications Ltd., 1985), p. 48; Robin Law, op. cit., p. 193.

[19]. J.A. Atanda, An Introduction to Yoruba History (Ibadan: Ibadan University Press, 1980), p. 30

[20]. I.A. Akinjogbin 'The Prelude to the Yoruba Civil Wars of the Nineteenth Century', Odu, University of Ife Journal of African Studies, 1,2, pp. 24-46.

[21]. E.A. Ayandele, Nigerian Historical Studies (London: Frank Cass, 1979), p. 19.

[22]. J.A. Atanda, An Introduction to Yoruba History (Ibadan: Ibadan University Press, 1980), p. 32.

[23]. G.O.O. Olomola, Aduloju of Ado-Ekiti. A Case Study of An Ekiti Warrior Chief of the Nineteenth Century, pp. 3-4.

[24]. Ibid.

[25]. Samuel Johnson, The History of the Yoruba, p. 288. For a detailed analysis of the causes, course and consequences of the war, see J.F.A. Ajayi \& Robert Smith, Yoruba Warfare in the $19^{\text {th }}$ Century (Ibadan: Ibadan University Press, 1973), pp. 33-36.

[26]. S.A. Akintoye, 'The EkitiParapo and Kiriji War', Ph.D Thesis, University of Ibadan, 1967, p. 296. For a fairly detailed examination of some of the reasons that were responsible for Ibadan's imperialism in Ekiti and Ijesa areas, see S.A. Akintoye, Revolution and Power Politics in Yorubaland, 1840-1893, p. 41.

[27]. The ajele was a resident representative of Ibadan in a vassal town. For a detailed discussion on the emergence, practise and consequences of the ajele system, see Bolanle Awe, "The Ajele System", Journal of the Historical Society of Nigeria, Vol. III, No. 1, December 1964, pp. 57-58.

[28]. J.F.A. Ajayi \& Robert Smith, Yoruba Warfare in the Nineteenth Century (Ibadan: Ibadan University Press, 1964$)$, p. 69.

[29]. Quoted from S.A. Akintoye, Revolution and Power Politics in Yorubaland, p. 70.

[30]. Ibid, p. 72

[31]. G.O.O. Olomola, op. cit., p. 6. See also Olatunji Ojo "Ethnic Identity and Nineteenth Century Yoruba Warfare", op. cit.

[32]. Interview with Chief J.B. Aduloju, 71, the Edemo of Ado-Ekiti and head of the Aduloju family, Odo-Ado, Ado-Ekiti, 20 February 2013.

[33]. Rev. A Oguntuyi, op. cit., p. 19.

[34]. Interview with Chief Akinwumi Michael, 76, the Ejemina of Ado-Ekiti, Edemo's Compound, Odo-Ado, Ado-Ekiti, 23 February 2013.

[35]. Ewi is the title of the oba (king) of Ad Ekiti.

[36]. Interview with Jeje James, 50, Okesa, Ado-Ekiti, 27 February 2013.

[37]. Toyin Falola \& G.O. Oguntomisin, Yoruba Warlords of the $19^{\text {th }}$ Century, op. cit., p. 85.

[38]. Interview with Jimoh Arogundade, c.49, Odo-Ado, Ado-Ekiti, 13 March 2013.

[39]. P.C. Lloyd, Yoruba Land Law (Oxford: Oxford University Press, 1962), p. 188.

[40]. The Ijesa declared war because, during this period, Ibadan, who had succeeded the Oyo Empire as the police of Yorubaland, was engrossed with the Ijaye War.

[41]. G.O.O. Olomola, op. cit., p. 10.

[42]. Ogedengbe's exact date of birth is not known but available evidence seem to suggest that he was born in the first decade of the $19^{\text {th }}$ century. He died in 1910. In the 1850s, he left for Ibadan where he became a soldier-in-training of Akiiko, the Balogun of Ogunmola's private army. Ogedengbe learnt fast and soon distinguished himself as a war-boy. He left Ibadan for Ilesa in 1867 and built a formidable private army. For his career and exploits, see Toyin Falola \& Dare Oguntomisin, Yoruba Warlords, pp. 95-108; Amusa Saheed Balogun, "Ogedengbe Agbogungboro of Ilesa: A $19^{\text {th }}$ Century Yoruba Warlord" in Siyan Oyeweso (ed.), Ijesa Icons \& the Making of Modern Nigeria, College of Humanities and Culture, Osun State University, 2011, pp. 4\&11.

[43]. Interview with Chief J.B Aduloju, op. cit

[44]. Interview with Chief Ojo Bejide, 77, No 23, Irare Street, Efon Alaaye, 29 March 2013. See also Samuel Johnson, op. cit., p. 323.

[45]. These were Ogunleye, Ayogun, Ologbe, Osamekun, Ologbo and Ifajire. See Rev. Oguntuyi, p. 28.

[46]. Oguntuyi estimated that Aduloju spent ten years at Obo, Ibid.

[47]. Toyin Falola \& Dare Oguntomisin, The Military in Nineteenth Century Yoruba Politics, pp. 107-108.

[48]. Ibid., p. 108.

[49]. Rev. Oguntuyi, p. 29.

[50]. Interview with Akinbaye Tope, 55, Odo-Ado, Ado-Ekiti, 15 March 2013.

[51]. Revolution and Power Politics in Yorubaland, 1840-1893, p. 63.

[52]. Aduloju was said to have initially declined his appointment as Balogun exclaiming that 'Baba mi Ala ni Balogun' meaning 'my father Ala is the Balogun'. But the whole gathering insisted that they had had enough of Ala as Balogun. See Rev. Oguntuyi, op. cit., p. 35 .

[53]. G.O.O. Olomola, p. 15.

[54]. Oguntuyi, p. 39.

[55]. National Achieves Ibadan: W.A.C. Weir, Intelligence Report on Akure District of Ekiti Division, Ondo Province, December, 1939, p.8.

[56]. Olomola, p. 16.

[57]. Ibid.

[58]. Interview with Peter Olowookere, 65, Odo-Ado, Ado-Ekiti, 15 March 2013.

[59]. W.A.C. Weir, op. cit., p.18. 
[60]. For a brief discussion of the reasons that informed Aduloju's decision, see G.O. Olomola, pp. 20-21..

[61]. 'Ekitiparapo' literally means Ekiti unite. This is the name given to the 1873-1886 war in which eastern Yoruba towns sought to throw off Ibadan imperial yoke.

[62]. Ibid, p. 23

[63]. S.A. Akintoye, Revolution and Power Politics in Yorubaland, 1840-1893, p. 93.

[64]. Ibid

[65]. Ibid,

[66]. Olomola, p. 26.

[67]. Ibid, p. 28

[68]. Samuel Johnson, History of the Yoruba, p. 645. The arrest of the so-called 'troublesome spirits' was continued by Captain Tucker, Bower's successor.

[69]. Rev. Oguntuyi, p. 53.

[70]. Following Aduloju's arrest by 30 Hausa soldiers, about 1,800 of his boys and followers fled from the Lasigidi camp while another 600 fled his expansive farm at Igbira, near Ijan, Rev. Oguntuyi, p. 53. Chief Michael Akinwumi put the number of those who fled the Lasigidi camp and Igbara farm at 2,000 and 800 respectively. Interview, 23 February 2013.

[71]. Interview with Chief J.B. Aduloju, 71, the Edemo of Ado-Ekiti and head of the Aduloju family, Odo-Ado, Ado-Ekiti, 20 February 2013.

[72]. Oguntuyi, p. 57. 